\title{
USE OF HYDROGEN PEROXIDE, CITRIC ACID AND SODIUM HYPOCHLORITE AS SANITIZER FOR MINIMALLY PROCESSED TABLE GRAPES
}

\author{
UTILIZAÇÃO DE PERÓXIDO DE HIDROGÉNIO, ÁCIDO CÍTRICO E HIPOCLORITO DE SÓDIO \\ COMO DESINFETANTE PARA UVAS DE MESA MÍNIMAMENTE PROCESSADAS
}

\begin{abstract}
Muharrem Ergun*, Ezgi Dogan
Bingol University, Department of Horticulture, Bingol, Turkey, 12100.

*corresponding author: Tel: +905057518147, email: muharrem.ergun@yahoo.com

(Received 01.10.2017. Accepted 16.05.2018)

SUMMARY

The objective of this study was to explore two local table grape cultivars, one is white and the other one red colored, as a minimally processed produce, and to identify the most effective sanitizers (hydrogen peroxide, citric acid or sodium hypochlorite) to control microbial growth. The table grape cultivars indigenous to Elazig province of Turkey 'Agin Beyazi' and 'Agin Kirmizisi' were tested in the present experiment. Grape clusters were washed by dipping in tap water as control, in citric acid $(20 \mathrm{~g} / \mathrm{L})$, with sodium hypochlorite $(50 \mathrm{mg} / \mathrm{L})$, or with hydrogen peroxide $(20 \mathrm{~g} / \mathrm{L})$, solutions for 1 minute. Grape berries were then placed into PET clamshells and kept at $4{ }^{\circ} \mathrm{C}$ for 10 days. The berries were subject to quality assessments during the storage, and to total aerobic microbial and fungal count at the end. Washing with hydrogen peroxide- or sodium hypochlorite-diluted water was very effective controlling both aerobic microbial and fungal growth. Citric acid treatment however represented no significant effect on microbial growth. It is concluded that both hydrogen peroxide and sodium hypochlorite are strong sanitizers for table grapes tested, with no detection of undesirable effects.
\end{abstract}

\section{RESUMO}

O objetivo do presente estudo foi investigar duas cultivares locais de uva de mesa, uma de cor branca e a outra de coloração vermelha, como produto minimamente processado e para identificar os desinfetantes mais eficazes (peróxido de hidrogénio, ácido cítrico ou hipoclorito de sódio no controlo do crescimento microbiano. As cultivares de uva de mesa autóctones, 'Agin Beyazi' e 'Agin Kirmizisi' da província de Elazig, Turquia, foram as utilizadas no presente estudo. Os cachos de uva foram lavados por imersão em água da torneira como controle, em soluções de ácido cítrico $(20 \mathrm{~g} / \mathrm{L})$, de hipoclorito de sódio $(50 \mathrm{mg} / \mathrm{L})$ e de peróxido de hidrogénio $(20 \mathrm{~g} / \mathrm{L})$ durante 1 minuto. As uvas foram depois colocadas em embalagens de PET e mantidas a $4{ }^{\circ} \mathrm{C}$ por dez dias. Os bagos foram sujeitos a avaliações da qualidade durante o armazenamento e no final foi feita contagem de microrganismos mesófilos aeróbios totais e fungos. A lavagem com soluções de peróxido de hidrogênio ou de hipoclorito de sódio foi muito eficaz no controle do crescimento dos microrganismos aeróbios e dos fungos. O tratamento com ácido cítrico, no entanto, não apresentou efeito significativo sobre o crescimento microbiano. Concluiu-se que, tanto o peróxido de hidrogénio como o hipoclorito de sódio são bons desinfetantes para as uvas de mesa testadas, sem se registarem quaisquer efeitos indesejáveis.

Key words: citric acid, hydrogen peroxide, ready-to-eat, sodium hypochlorite, table grape.

Palavras-chave: ácido cítrico, peróxido de hidrogénio, pronto a comer, hipoclorito de sódio, uvas de mesa.

\section{INTRODUCTION}

The consumption of fresh-cut and minimally processed fruits and vegetables are constantly rising due to their fresh-like attributes compare to processed fruits and vegetables. Their fresh-like taste and rich phytochemical trait make fresh cut or minimally processed produce superior with respect to processed produce such as drying or freezing (Kaur and Kapoor, 2001; Del Caro et al., 2004). Fresh-cut or minimally processed fruits are however shorter shelf life compared to their counter parts. Thus, most of the scientific research for fresh-cut or minimally processed produce aims to know how to prepare and how to extend their shelf life. Washing, brushing, hypothermic storage, modified atmosphere packaging, hot water treatment and coating with natural products are the most used practices for freshcut or minimally processed produce (Soliva-Fortuny

This is an Open Access article distributed under the terms of the Creative Commons Attribution License (http://creativecommons.org/licenses/by/4.0), which permits unrestricted use, distribution, and reproduction in any medium, provided the original work is properly cited. 
and Martin-Belloso, 2003; Rico et al., 2007; Gonzalez-Aguilar et al., 2009).

New horticultural products have been continuously introduced as fresh-cut or minimally processed, sometimes referred ready-to-eat; table grapes are one of the example for these products. Minimally processed table grapes are very easy to prepare: first washing, second removing berries from pedicels and tori, and finally packaging (Mattiuz et al., 2004; Conte et al., 2007; Ergun et al., 2008). Red table grapes seem to be more suitable for minimal processing as opposed to white table grapes (Mattiuz et al., 2004). Minimally processed grapes have potential to replacing some snacks for not only household consumption but other places such as schools, workplaces, aircrafts, watercrafts.

Decay and other non-decay-related quality losses both of which are mostly attributed to removal of pedicels and tori are the two major problems facing by minimally processed table grapes (Kou et al., 2006a,b; Ergun et al., 2008). Chlorine, ethanol, hot water treatments, modified atmosphere packaging and coating by Aleo vera jel have been found the most effective practices so far by researchers in order to prevent or suppress decay development in minimally processed table grapes (Conte et al., 2007; Costa et al., 2011; Alberio et al., 2015).

Chlorine is probably the most used sanitizer for freshcut or minimally processed fruits or vegetables (Gil et al., 2009). The use of chlorine or chlorine-based disinfectant is nevertheless confronted with some negativity rose by environmentalists or naturalists (Parish et al., 2003). Some EU countries have already banned the use of sodium hypochlorite in fresh-cut produce (Ölmez and Kretzschmar, 2009). Hydrogen peroxide has gained attention by researches as a vigorous bactericide and sporicide (Pérez-Gregorio et al., 2011). The sanitizer is effective on the microorganism by generating cytotoxic oxidative radicals such as hydroxyl radicals (Khadre and Yousef, 2001). Hydrogen peroxide is regarded a safe (GRAS) but in USA its use for food has some restrictions (Ölmez and Kretzschmar, 2009). Citric acid is also widely considered as safe (GRAS) additive since naturally present in fruits and vegetables and used to contain microbial proliferation in fresh-cut or minimally processed produce (Park et al., 2011).

Grapes are cultivated in very wide range of territories in the world, for example there are almost no zones where grapes are not cultivated in Turkey. Although consumed in several ways such as fresh (table grape), unfermented or fermented juice, raisins and molasses, there is still a surplus of grapes in Turkey. Thus, minimally processed table grapes would have potential to cut down this surplus by alluring more consumers. The present research aimed to explore two local table grape cultivars, one is white and the other one red colored, as a minimally processed produce and to identify the most effective sanitizers (hydrogen peroxide, citric acid or sodium hypochlorite) to control microbial growth in these minimally processed grapes stored at $4{ }^{\circ} \mathrm{C}$.

\section{MATERIAL AND METHODS}

\section{Plant materials}

'Agin Beyazi' and 'Agin Kirmizisi' table grape cultivars native to Elazig province of Turkey were employed in the present study (Figure 1). Both cultivars are broadly cultivated in Elazig providence and its neighbouring providence Malatya. 'Agin Beyazi' is a white while 'Agin Kirmizisi' a red coloured cultivar but both have a conical/cylindrical cluster with dense and large berries (250 - 300 g) carrying 2-3 seeds.

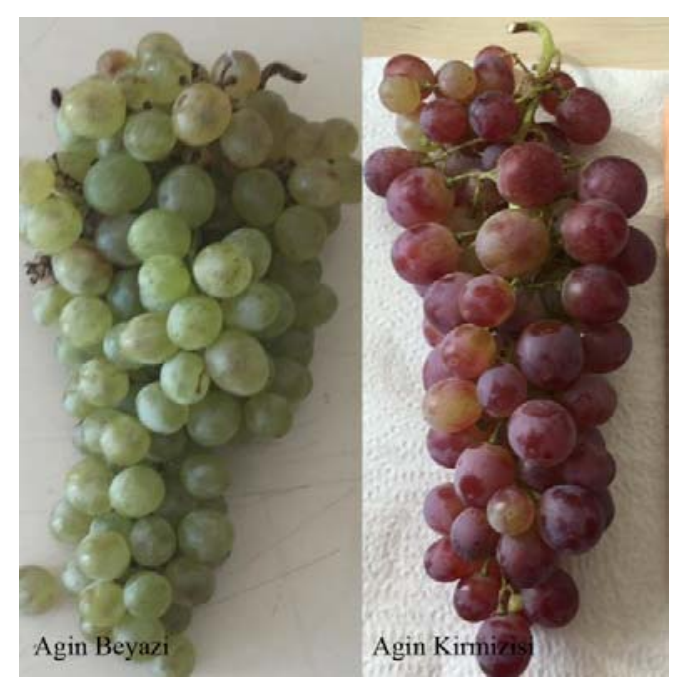

Figure 1. ‘Agin Beyazi’ and 'Agin Kirmizisi’ grape cultivars.

Uvas das cultivares 'Agin Beyazi' e 'Agin Kirmizisi'.

\section{Preparation for treatments}

The grapes at commercial ripeness were obtained from a farmer in Agin county of Elazig providence. Approximately $100 \mathrm{~kg}$ per grapes cultivar were used in the present study. Only superior grape clusters were selected to use in the experiment. The selected grapes were washed by immersing into tap water, citric acid (20 g/L), hydrogen peroxide $(20 \mathrm{~g} / \mathrm{L})$ or sodium chloride (50 mg/L) solutions for $1 \mathrm{~min}$. After 
draining and air-drying, the berries were removed from pedicels and/or tori by selecting only uniform ones in accord with size, color, shape, absence of decay and defect. The berries were packed into 250$\mathrm{mL}$ volume clamshells with a dimension of $2.5 \times 10 \mathrm{x}$ $10 \mathrm{~mL}$. The clamshells were then stored at $4{ }^{\circ} \mathrm{C}$ simulating the most common refrigeration temperature for 10 days which was decided by preliminary studies. Total 50 clamshells were prepared for each cultivar and each clamshell contained 20 uniform berries. During the storage, weight loss ratio, firmness, soluble solid content, $\mathrm{pH}$ and titratable acidity were measured every other day. At the end of storage period, package headspace $\mathrm{CO}_{2}$, $\mathrm{O}_{2}, \mathrm{NO}_{2}$ concentrations were measured along with enumeration of total aerobic microbial and fungal count.

\section{Weight loss and firmness determination}

Five clamshells from each treatment were weighed every other day and cumulative weight loss percentage was calculated. A total of five berries from five different clamshells were randomly selected for firmness. Firmness was measured by using TA-TX Plus Texture Analyzer (Stable Micro System Ltd., Surrey, UK). The puncture probe with 2-mm diameter was penetrated into a berry at the equatorial zone at a speed of $0.80 \mathrm{~mm} / \mathrm{s}$ with a deep of $5 \mathrm{~mm}$, the reading was registered as $\mathrm{N}$ (Newton, $\mathrm{Kg} \mathrm{m} / \mathrm{s}^{2}$ ).

\section{Soluble solid content, $\mathrm{pH}$ and titratable acidity quantifications}

Total five clamshells for each cultivar carrying 20 berries each were used to measure soluble solid content, $\mathrm{pH}$ and titratable acidity assessments. The berries were passed through a fruit juicer then centrifuged at a speed 2,000 rpm for 5 min to separate the juice. Soluble solid content was measured using a digital reflectometer (Krüss, Germany) and $\mathrm{pH}$, a pHmeter (Hanna, HI 2211, Woonsocket, RI, USA). For titratable acidity (\%) 6 g juice was titrated with $0.1 \mathrm{M} \mathrm{NaOH}$ until the $\mathrm{pH}$ reaching 8.2 with using automatic titrator (Automatic Potentiometric Titrator, AT-510; KEM Kyoto Elect., Tokyo, Japan). Titratable acidity was expressed as percent tartaric acid.

\section{Gas composition analyses}

$\mathrm{CO}_{2}, \mathrm{O}_{2}$ and $\mathrm{N}_{2}$ headspace gases in the clamshell were analysed by a gas analyzer (Systech Inst., Gaspace Advance, GS3/L; Johnsburg, IL, USA) and expressed as percentage at the end of the storage period. Five clamshells per treatment were used for the head space analyses. The clamshells had been untouched until the measurement done.

\section{Total aerobic microbial and fungal count}

One sample of $25 \mathrm{~g}$ of berries per clamshell was used for the counts. Plate Count Agar (PCA) was employed for total aerobic microbial count (TAMC) and Sabouraud Dextrose Agar (SDA) for total fungal count (TFC). The berry samples (25 g) were homogenized in a stomacher bag with 225-mL sterilized peptone water. The homogenate was then diluted until $10^{-6}$, when needed. The diluted sample was inoculated into PCA or SDA media. For TAMC, the pour plate and for TFC, the spread plated method was used. One mL-diluted homogenate was transferred to a sterilized petri dish, then $15 \mathrm{~mL}$ PCA which had been sterilized in autoclave at $121^{\circ} \mathrm{C}$ and 1 atm for $15 \mathrm{~min}$ and cooled down to $45{ }^{\circ} \mathrm{C}$ was poured onto the diluted homogenate. The agar and the homogenate were mixed to get a uniform media. The petri dish was then incubated at $35{ }^{\circ} \mathrm{C}$ for 48 hours, later all colonies were counted and expressed as colony forming unit per $\mathrm{ml}$ (CFU/mL). 100- $\mu \mathrm{L}$ diluted homogenates were inoculated on the SDA, then spread all over the media by a drigalsky spatula. The petri dishes containing the homogenate and SDA were then incubated at $25{ }^{\circ} \mathrm{C}$ for 72 hours and colonies were counted (CFU/mL).

\section{Statistical analysis}

The treatment design was Randomized Complete Blok Design with five replications. Data were analyzed by ANOVA, with mean separation by Duncan test at 0.05 level using SAS software (SAS, Carry, NC, USA).

\section{RESULTS AND DISCUSSION}

\section{Weight and firmness loss}

Changes in weight and firmness are often linked to changes in quality of fresh fruits and vegetables. Thus, a loss of the both parameters in table grapes means an exacerbation on the quality as well. Irrespective of the cultivars and treatments, weight changes were very diminutive and insignificant for the grapes kept in the clamshells in the course of the storage, indicating that the film of the clamshell provided a very restricted barrier not allowing a significant a water vapor exchange (Figure 2). Water loss from an intact grape berry occurs through cuticle whose biochemical and physical structure depends on the cultivar, ripeness, harvest stage, climatic and cultural conditions (Possingham et al., 1967). Minimally processed are more susceptible to water loss due to detached pedicels or tori. Removal of tori crates wounds which hastens water loos and even possibly firmness loss (Lo'ay and Dawood, 2017). 


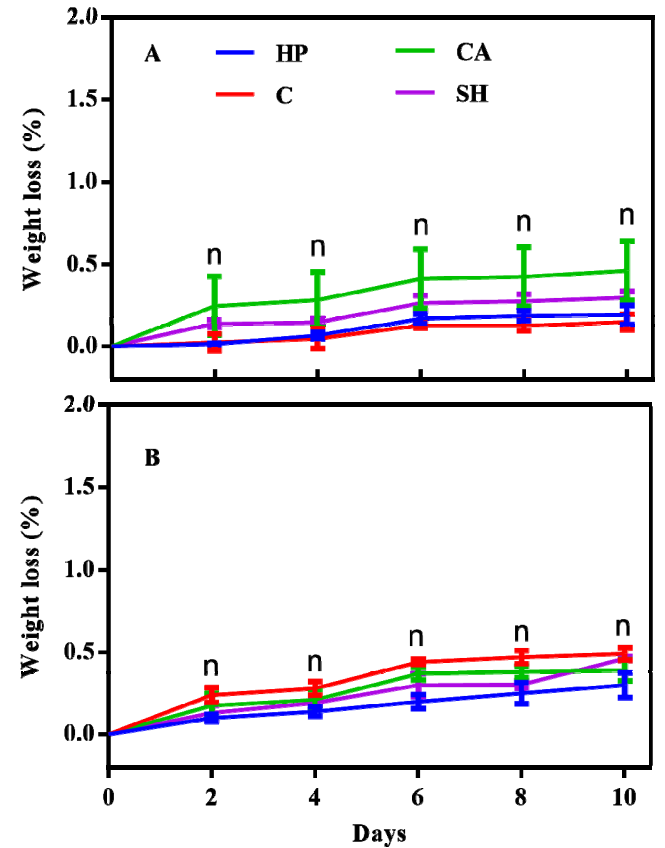

Figure 2. Weight loss percentage of 'Agin Beyazi' (A) and 'Agin Kirmizisi' (B) grape cultivars during 10-day cold storage at $4{ }^{\circ} \mathrm{C}$. Grapes treatment: HP - hydrogen peroxide solution $(20 \mathrm{~g} / \mathrm{L})$; C tap water as control; CA - citric acid solution $(20 \mathrm{~g} / \mathrm{L})$; and $\mathrm{SH}$ sodium hypochlorite solution $(50 \mathrm{~g} / \mathrm{L})$. Values represent means of five determinations and bars represent the standard deviation. Means followed by the same letters on the same day are not significantly different by Duncan test $\mathrm{p}<0.05$. n: not significant.

Percentagem de perda de peso de uvas das cultivares 'Agin Beyazi' (A) e 'Agin Kirmizisi'(B) durante 10 dias de armazenamento a 4 ${ }^{\circ}$ C. Tratamento das uvas: HP - solução de peroxide de hidrogénio $(20 \mathrm{~g} / \mathrm{L}) ; C$ - água da torneira como controle; $C A$ - solução de ácido cítrico $(20 \mathrm{~g} / \mathrm{L})$; e solução de hipoclorito de sódio $(50 \mathrm{~g} / \mathrm{L})$. Os valores representam médias de cinco determinações e as barras representam o desvio padrão. Médias seguidas pelas mesmas letras no mesmo dia não são significativamente diferentes pelo teste Duncan $p<0.05$. n: não significativo.

Grape berries were slightly softened during the storage period (Figure 3 ). The fact that sanitizers do not hasten or suppress softening in both cultivars may indicate that the concentrations tested are innocuous to not affecting firmness in table grapes. Indeed, the sanitizers used in the present experiment are abrasive cleaners and expected to have minor damages in cuticle (Fava et al., 2011) but their concentration was very low to have a measurable effect on firmness loss in which enzymatic hydrolysis of cell wall pectin or pectin-base structures, pectinolytic enzyme activities, decreases in crystallinity and thinning cell walls are thought be responsible (Qi et al., 2011).

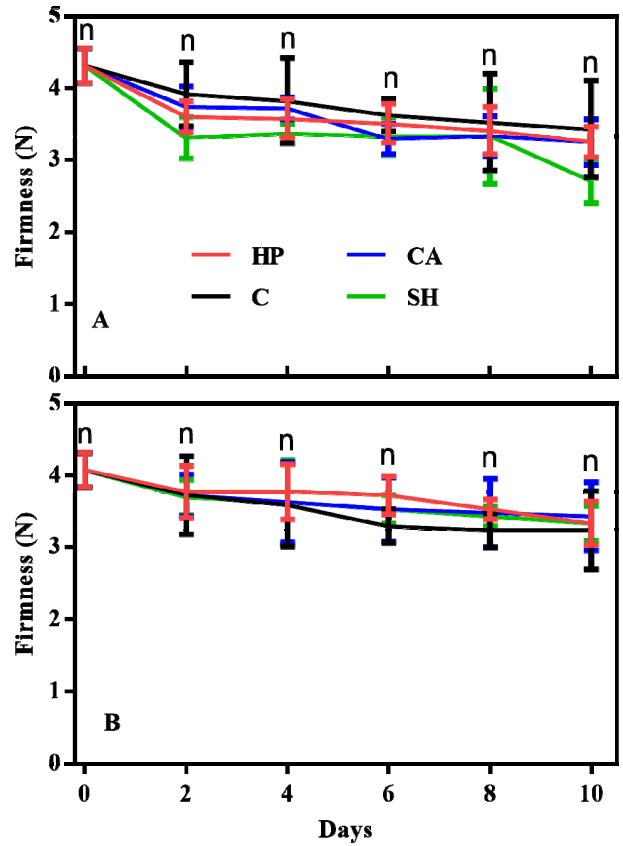

Figure 3. Firmness of 'Agin Beyazi' (A) and 'Agin Kirmizisi' (B) grape cultivars during 10-day cold storage at $4{ }^{\circ} \mathrm{C}$. Treatment abbreviations are the same as in Figure 2.

Firmeza de uvas das cultivares 'Agin Beyaz' (A) e 'Asin Kirmizisi' (B) durante dez dias de armazenamento a $4{ }^{\circ} \mathrm{C}$. Abreviaturas de tratamento são as mesmas que na Figura 2.

\section{Soluble solid content, $\mathrm{pH}$ and titratable acidity}

Soluble solid content (SSC) of both cultivars showed minute but insignificant changes during storage (Figure 4). Thus, the sanitation treatments caused no pronounced effects on SSC in both cultivars. Values of $\mathrm{pH}$ in both cultivars slightly increased until day 6 then stayed steady or slightly decreased through the end of the storage (Figure 5). Both cultivars have seemed to have equivalent $\mathrm{pH}$ values when compared to each other. Similar to $\mathrm{SSC}, \mathrm{pH}$ values in both cultivars were statistically steady during storage irrespective of the sanitizers. TA percentage of 'Agin Beyazi' first increased then decrease and finally reached the initial values at the end of the storage (Figure 6). TA percentage of 'Agin Kirmizisi' first decreased then increase and once more minutely decreased though the end of storage (Figure 6). The sanitizers induced no notable effects on TA for both cultivars. The sanitizers tested in the present experiment caused no undesirable effects on SSC, $\mathrm{pH}$ or TA, indicating that their concentrations may be innocuous to use in the washing process of minimally processed gapes. 


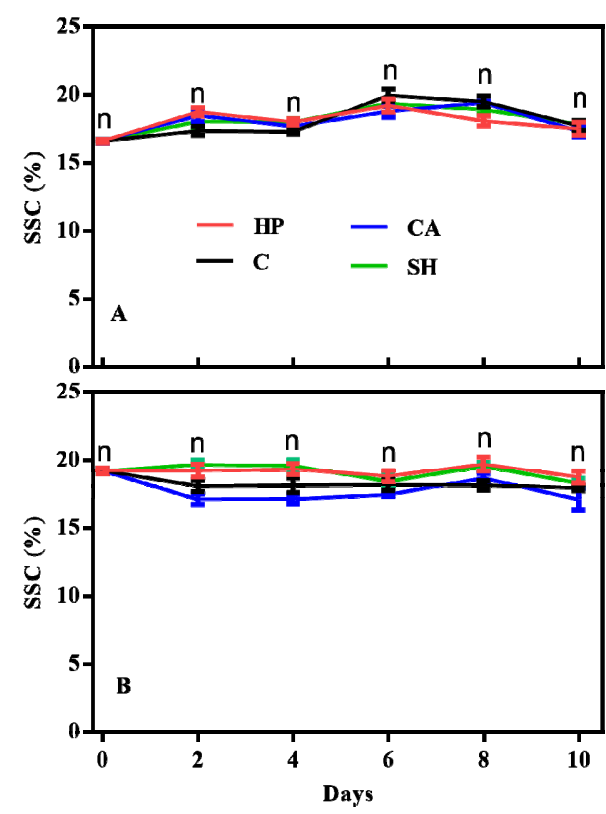

Figure 4. Soluble solid content (SSC) of 'Agin Beyazi' (A) and 'Agin Kirmizisi' (B)' grape cultivars during 10-day cold storage at $4{ }^{\circ} \mathrm{C}$. Treatment abbreviations are the same as in Figure 2.

Teor de sólidos solúveis de uvas das cultivares Agin Beyazi'(A) e 'Agin Kirmizisi' (B) durante dez dias de armazenamento a $4{ }^{\circ} \mathrm{C}$. Abreviaturas de tratamento são as mesmas que na Figura 2.

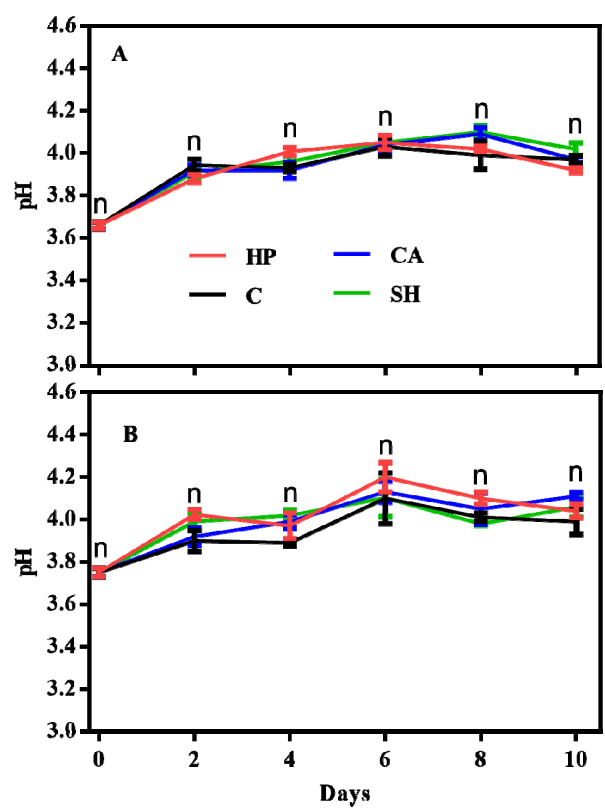

Figure 5. pH levels of 'Agin Beyazi' (A) and 'Agin Kirmizisi' (B) grape cultivars during 10-day cold storage at $4{ }^{\circ} \mathrm{C}$. Treatment abbreviations are the same as in Figure 2.

Valores de pH de uvas das cultivares Agin Beyazi'(A) e 'Agin Kirmizisi' (B) durante dez dias de armazenamento a $4{ }^{\circ} \mathrm{C}$. Abreviaturas de tratamento são as mesmas que na Figura 2.

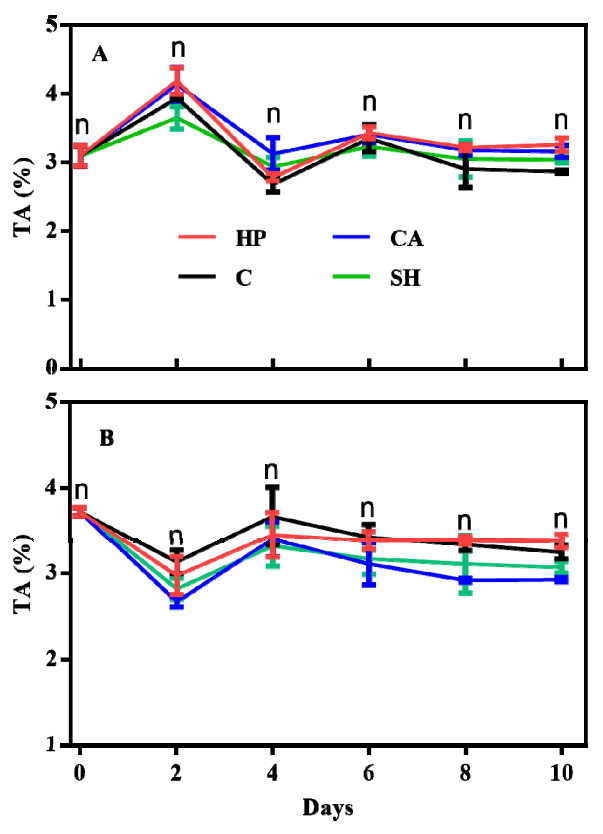

Figure 6. Titratable acidity (TA, \%) of 'Agin Beyazi' (A) and 'Agin Kirmizisi' (B) grape cultivars during 10-day cold storage at 4 ${ }^{\circ} \mathrm{C}$. Treatment abbreviations are the same as in Figure 2.

Acidez titulável (AT, \%) de uvas das cultivares 'Agin Beyazi'(A) e 'Agin Kirmizisi' (B) durante dez dias de armazenamento a $4{ }^{\circ} \mathrm{C}$

Abreviaturas de tratamento são as mesmas que na Figura 2.

\section{Package headspace gas composition}

Package headspace gas composition of grapes was measured in undisturbed clamshells at the end of the storage period (Figure 7). The control grapes registered significantly higher $\mathrm{CO}_{2}$ percentage compared to especially CA-treated grapes. The cultivar 'Agin Kirmizisi' registered much the same as the other cultivar in terms of package $\mathrm{CO}_{2}$ content. Control berries of 'Agin Kirmizisi' displayed a significantly higher $\mathrm{CO}_{2}$ content over $\mathrm{CA}$ - and $\mathrm{SH}$ treated grapes. $\mathrm{O}_{2}$ content, as expected, was reverse image of the $\mathrm{CO}_{2}$ content for both the cultivars and treatments. Control berries irrespective of cultivars registered a lower $\mathrm{O}_{2}$ content compared to other treatments. Sanitizer-treated berries registered lower $\mathrm{N}_{2}$ content for both cultivars.

The variation in headspace gas composition was most likely caused by respiratory activity of berries which resulted in higher $\mathrm{CO}_{2}$ and lower $\mathrm{O}_{2}$ and $\mathrm{N}_{2}$ concentration in a closed system. In the present experiment especially citric acid and sodium hypochlorite treatments caused a lower rate of $\mathrm{CO}_{2}$ possibly due to suppressing respiratory activity by creating an oxygen barrier on the surface of berries (Qi et al., 2011). 

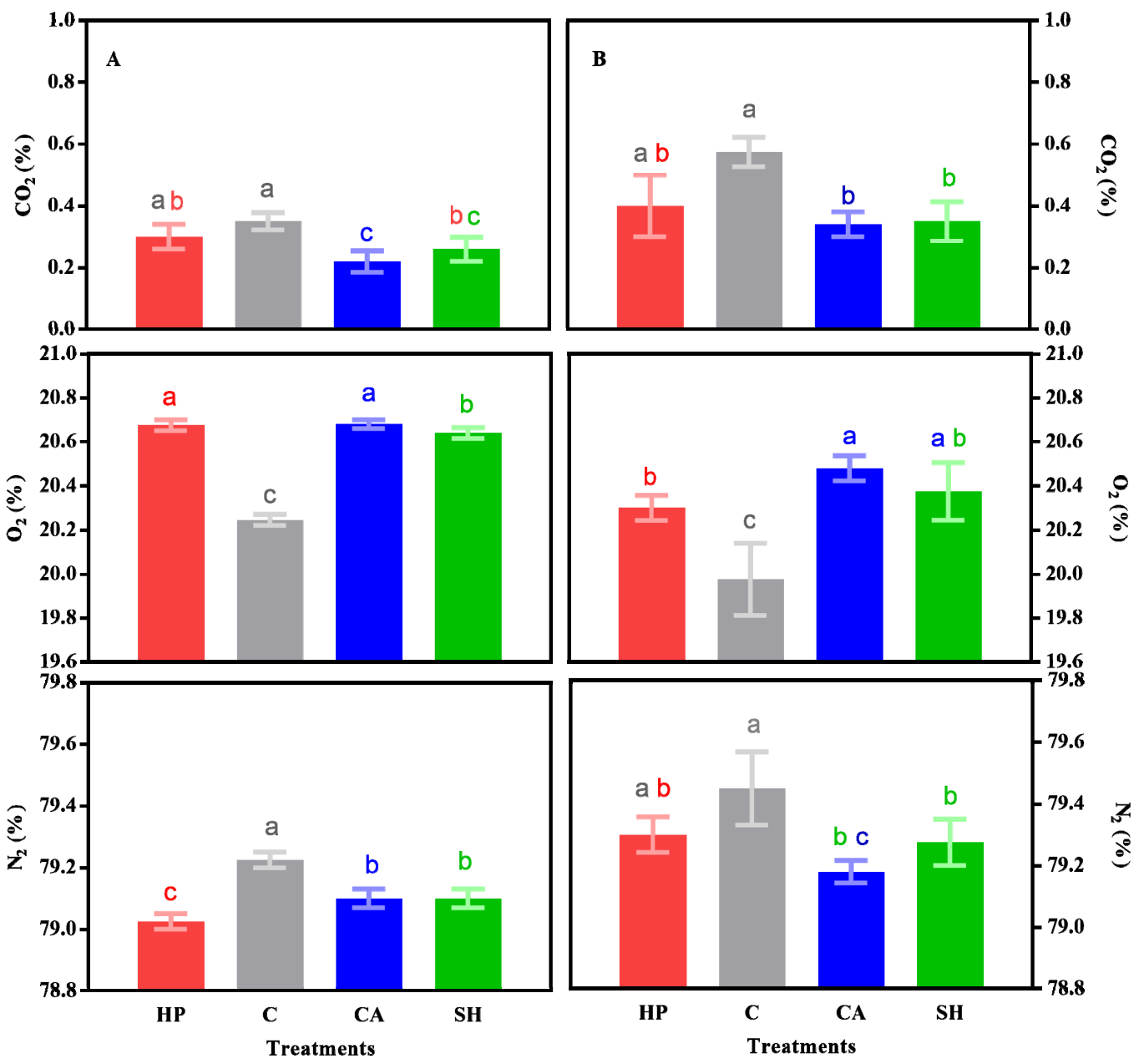

Figure 7. Package headspace $\mathrm{CO}_{2}, \mathrm{O}_{2}$ and $\mathrm{N}_{2}$ concentration (\%) of 'Agin Beyazi' (A) and 'Agin Kirmizisi' (B) grape cultivars at the end of storage period at $4{ }^{\circ} \mathrm{C}$. Treatment abbreviations are the same as in Figure 2.

Concentração (\%) de $\mathrm{CO}_{2}, \mathrm{O}_{2}$ e $\mathrm{N}_{2}$ nas embalagens de uvas das cultivares 'Agin Beyazi' (A) e 'Agin Kırmizisi' (B) no final do periodo de armazenagem a $4{ }^{\circ} \mathrm{C}$. Abreviaturas de tratamento são as mesmas que na Figura 2.

\section{Total aerobic microbial and fungal count}

The total aerobic microbial and fungal loads of the berries are reported in Figure 8. Statistical differences were found among treatments and between cultivars as well. On the last day of the experiment the highest aerobic microorganism growth was detected in control grapes followed by CA-treated ones of both cultivars. Grapes washed with HP or SH solution had lower aerobic microbial proliferation in both cultivars. 'Agin Beyazi' registered higher loads than 'Agin Kirmizisi'.

Fungal growth was also recorded in both cultivars irrespective of treatments, however, similar to aerobic microbial increase, their proliferation varied according to treatments. Grapes washed only with water (control) and CA solution registered almost the same TFC values in both cultivars. On the other hand, grapes washed with HP- or SH solution recorded very low counts over control or CA treatments in both cultivars.

Besides the sanitizers tested in the present study, different sanitizers or organic-based compounds, such as chlorine dioxide, eugenol and thymol, have been found to be effective suppressing microbial proliferation in table grapes. Chlorine dioxide significantly restrained fungus and bacterial growth in 'Alphonse Lavallée' grapes stored at $4{ }^{\circ} \mathrm{C}$ for 15 days (Çelikkol and Türkben, 2012). Detrainments in microbial population in treated grapes with eugenol or thymol were also observed by Valero et al. (2006) and Guillén et al. (2007). 

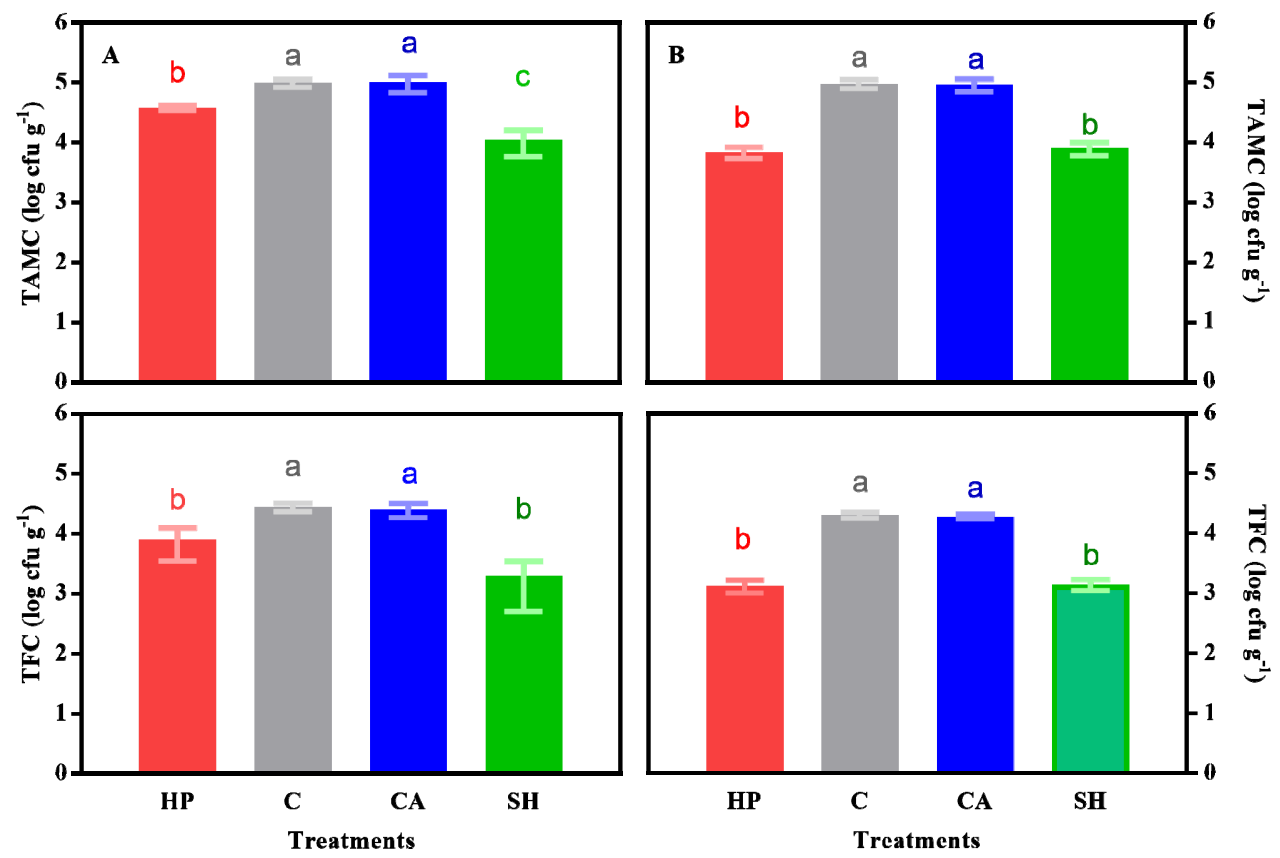

Figure 8. Total aerobic microbial count (TAMC) and total fungal count (TFC) of 'Agin Beyazi' and 'Agin Kirmizisi' (B) grape cultivars at the end of storage period at $4{ }^{\circ} \mathrm{C}$. Treatment abbreviations are the same as in Figure 2

Contagem de microrganismos aeróbios totais (TAMC) e contagem de fungos totais (CTF em uvas das cultivares "Agin Beyazi' (A) e 'Agin Kirmizisi' (B) no final do periodo de armazenagem a $4{ }^{\circ} \mathrm{C}$. Abreviaturas de tratamento são as mesmas que na Figura 2.

HP is a strong oxidizer, which makes it to be a good antimicrobial agent. The antimicrobial effect of HP covers bacteria, molds, fungi, viruses and bacterium spores. HP can also be effective on anaerobic microorganism because these organisms lack of catalase activity. Fungi are more resistant to HP compared to other microbes (Russell et al., 1992). $\mathrm{SH}$, a good oxidizer much the same as HP, kills microorganisms by damaging cell membrane and cell wall components, and by degeneration various cellular macromolecules or organelles. Thus, their antimicrobial effect on the grapes tested was not surprising and expected. CA was not effective on suppressing either aerobic microorganisms or fungi. Previous researches have mentioned ambivalent effects of CA on microbial growth. For example, the incompetence of $\mathrm{CA}(0.6 \%)$ on controlling of microbial growth was reported for fresh-cut lettuce kept $5{ }^{\circ} \mathrm{C}$ (Zhang and Yang, 2017). The same researchers however found that HP (1\%) was able to suppress microbial growth in the fresh-cut lettuce. On the other hand, Chen et al. (2016) reported that a lower CA concentration $(0.5 \%)$ was able to retarded microbial growth in fresh-cut 'Fuji' apples stored at 5 ${ }^{\circ} \mathrm{C}$. Thus CA effect on microbial growth is probably affected plant type, parts and other intrinsic characteristics.

TAMC and TFC indicate washing with tap water or citric acid solution at the selected concentration is not enough to prevent or suppress aerobic microbial or fungal growth in minimally processed grapes of the cultivars tested.

\section{CONCLUSIONS}

In present study, quality parameters of weight loss, firmness, soluble solids, $\mathrm{pH}$ and titratable acidity suggest both cultivars may be used as minimally processed grapes. Moreover, washing the grapes with hydrogen peroxide or sodium hypochlorite solutions was very effective on controlling aerobic and fungal microbial proliferation commonly considered as the chief responsible for quality loss in minimally grapes. Besides controlling microbial proliferation, the sanitizers did not alter the intrinsic characteristics of the grapes, indicating that they may be used in the washing process of minimally grapes. 


\section{REFERENCES}

Alberio G.R.A., Muratore G., Liciardello F., Giardina G., Spagna G., 2015. Aloe vera extract as a promising treatment for the quality maintenance of minimally-processed table grapes. Food Sci. Tecnol., Campinas, 35, 299-306.

Celikkol I., Türkben C., 2012. Effects of postharvest applications on berry quality, microbial population and morphological (epicuticular wax) deterioration of ready-to-eat table grapes. $J$. Food Agri. Environ., 10, 213-220.

Chen C., Hu W., He Y., Jiang A., Zhang R., 2016. Effect of citric acid combined with UV-C on the quality of fresh-cut apples. Postharvest Biol. Tech.., 111, 126-131.

Conte A., Scrocco C., Brescia I., Speranza B., Sinigaglia M., Antonacci D., Del Nobile M.A., La Notte E., 2007. Study of quality decay kinetic of minimally processed grape. In: Proceedings of the XXXTh World Congress of Vine and Wine, $\mathrm{Cd}$ Room, Budapest.

Costa C., Lucera A., Conte A., Mastromatteo M., Speranza B., Antaonacci A., Del Nobile M.A., 2011. Effects of passive and active modified atmosphere packaging conditions on ready-to-eat table grape. J. Food Eng., 102, 115-121.

Del Caro A., Piga A., Vacca V., Agabbio M., 2004. Changes of flavonoids, vitamin $\mathrm{C}$ and antioxidant capacity in minimally processed citrus segments and juices during storage. Food Chem., 84, 99-105.

Ergun M, Akkaya O, Ergun N., 2008. Suitability of some midseason table grape cultivars and types for minimally processed produce. J. Int. Sci. Vigne Vin., 42, 99-106.

Fava J., Hodara K., Nieto A., Guerroro S., Alzamora S.M., Castro M.A. 2011. Structure (micro, ultra, nano), color and mechanical properties of Vitis labrusca L. (grape berry) fruits treated by hydrogen peroxide, UV-C irradiation and ultrasound. Food Res. Int., 44, 2938-29487.

Gil M.I., Selma M.V., López-Gálvez F., Allende A., 2009. Freshcut product sanitation and wash water disinfection: Problems and solutions. Int. J. Food Microbiol., 134, 37-45.

Gonzalez-Aguilar G.A., Valenzuela-Soto E., Lizardi-Mendoza J., Goycoolea F., Martínez-Téllez M.A., Villegas-Ochoa M.A., Monroy-García I.N., Ayala-Zavala J.F., 2009. Effect of chitosan coating in preventing deterioration and preserving the quality of fresh-cut papaya 'Maradol'. J. Sci. Food Agric., 89, 15-23.

Guillén F., Zapata P.J., Martínez-Romero D., Castillo S., Serrano M., Valero D., 2007. Improvement of the overall quality of table grapes stored under modified atmosphere packaging in combination with natural antimicrobial compounds. J. Food Sci., 72, 185-190.

Kaur C., Kapoor H.C., 2001. Antioxidants in fruits and vegetables - the millennium's health. Int. Food Sci. Tech., 36, 703-725.

Khadre M.A., Yousef A.E., 2001. Sporicidal action of ozone and hydrogen peroxide: a comparative study. Int. J. Food Microbiol., 71, 131-138.

Kou L., Liu X., Huang Y., Gao W., Yan X., 2006a. Effect of heat treatment on protective enzymes and membrane lipid peroxidation of lightly processed Red Globe grape. J. Chinese Food Sci. Technol., 6, 111-115.

Kou L., Liu X., Zdang C., Geng X., 2006b. Effects of respiratory intensity and storage quality of fresh-cut 'Kyoho' grape in hot water treatment. J. Food Ferment. Ind., 32, 143-146.

Lo'ay A.A., Dawood H.D. 2017. Active chitosan/PVA with ascorbic acid and berry quality of 'Superior seedless' grapes. Scientia Hort., 224, 286-292.

Mattiuz B.H., Carolina A., Miguel A., Nacthigal J.C., Durigan J.F., Camargon U.A., 2004. Processamento mínimo de uvas de mesa sem semente. Rev. Bras. Frutic., 26, 226-229.

Ölmez H., Kretzschmar U., 2009. Potential alternative disinfection methods for organic fresh-cut industry for minimizing water consumption and environmental impact. J. Food Sci. Technol., 42, 686-693.

Parish M.E., Beuchat L.R., Suslow T.V., Harris L.J., Garret E.H., Farbe J.N., Busta F.F., 2003. Methods to reduce/eliminate pathogens from fresh and fresh-cut produce. Compr. Rev. Food Sci. Food Saf., 2 (Suppl), 161-173.

Park S.H., Choi M.R., Park J.W., Park K.H., Chung M.S., Ryu S., Kang D.H., 2011. Use of organic acids to inactivate Escherichia coli O157:H7, Salmonella Typhimurium, and Listeria monocytogenes on organic fresh apples and lettuce. J. Food Sci., 76, M293-M298.

Pérez-Gregorio M.R., González-Barreiro C., Rial-Otero R., SimalGándara J., 2011. Comparison of sanitizing technologies on the quality appearance and antioxidant levels in onion slices. Food Control, 22, 2052-2058

Possingham J.V., Chambers T.C., Radler F., Grncarevic M., 1967. Cuticular transpiration and wax structure and composition of leaves and fruit of Vitis vinifera. Aust. J. Biol. Sci., 20, 1149-1153.

Qi H., Hu W., Jiang A., Tian M., Li Y., 2011. Extending shelf-life of Fresh-cut 'Fuji' apples with chitosan-coatings. Innov. Food Sci. Emerg. Technol., 12, 62-66.

Rico D., Martin-Diana A.B., Barat J.M., Barry-Ryan C., 2007. Extending and measuring the quality of fresh-cut fruit and vegetables: A review. Trends Food Sci. Tech., 18, 373-386.

Russell A.D., Hugo, W.B., Ayliffe, G.A.J., 1992. Disinfection mechanism. In: Principles and practice of disinfection, preservation and sterilization. 187-210. Oxford: Blackwell Scientific Publications.

Soliva-Fortuny R.C., Martin-Belloso O., 2003. New advances in extending the shelf-life of fresh-cut fruits: A review. Trends Food Sci. Tech., 14, 341-353.

Valero D., Valverde J.M., Martínez-Romero D., Guillén F., Castillo S., Serrano M., 2006. The combination of modified atmosphere packaging with eugenol or thymol to maintain quality, safety and functional properties of table grapes. Postharvest Biol. Tech., 41, 317-327.

Zhang J., Yang H., 2017. Effects of potential organic compatible sanitisers on organic and conventional fresh-cut lettuce (Lactuca sativa Var. Crispa L). Food Control, 72, 20-26. 